\title{
THE FOOTFALL OF SHOPPING CENTRES IN OLOMOUC (CZECH REPUBLIC): AN APPLICATION OF THE GRAVITY MODEL
}

\author{
Pavel KLAPKA, Martin ERLEBACH, Ondřej KRÁL, Michal LEHNERT, Tomáš MIČKA
}

\begin{abstract}
The issue of the footfall of large retail facilities in the city of Olomouc is treated in this article from the perspective of spatial interaction modelling. A production-constrained gravity model is applied to reveal spatial patterns of shopping travel intensities in the city. Three problems are addressed: the existing pattern and intensities of flows to the shopping centres; the prediction of possible future changes in these patterns and intensities; and inferences about hypothetical sizes of shopping centres according to some defined conditions.
\end{abstract}

\section{Shrnutí}

\section{Návštěvnost obchodních center v Olomouci (Česká republika): aplikace gravitačního modelu}

Článek se zabývá problematikou návštěvnosti velkých maloobchodních zařízení ve městě Olomouci z pohledu modelování prostorových interakcí. K odhalení prostorových vzori̊ a intenzit cest za nákupy ve struktuře města slouží produkčně omezený gravitační model. Zabýváme se třemi problémy: stávajícím vzorem a intensitami toků do nákupních center, predikcí možných budoucích změn těchto toků a jejich intensit a odvozením hypotetické velikosti nákupních center podle definovaných podmínek.

Key words: footfall, spatial interaction, gravity model, shopping centre, Olomouc, Czech Republic

\section{Introduction}

The first modern shopping centres started to appear in Czech cities during the second half of the 1990s. They were usually built on the city outskirts in "green" fields; with the advent of the millennium, industrial brownfields within larger city centres started to be adopted for retail facilities. Thus, the spatial location of shopping centres affects in a relatively significant way the organisation of urban space and the behaviours of city inhabitants and visitors (Berry, 1967; Birkin, Clarke, Clarke, 2002, for more on the issue in the Czech Republic, see Szczyrba, 2010). However, the intra-urban retail-based flows of persons are not easy to capture since there are no statistical data on such movements and/or the footfall ${ }^{1}$ of shopping centres is either a subject of trade secrets or it can be uncovered by a demanding questionnaire survey, sometimes disapproved of by the management of the shopping centres (for example in Moravia, see Kunc et al., 2011).
A useful possibility to tackle the problems of acquiring the necessary data is to resort to spatial interaction modelling, that is able not only to represent with a greater or lesser accuracy the actual flows, but also able to anticipate the future development of intraurban retail movements. The article sets the following general objective. We attempt to model the present and future intra-urban flows induced and attracted by shopping centres in the city of Olomouc, and use them to describe and analyze the modelled footfall of these shopping centres. We will make use of the gravity model to fulfil this objective. We also hope that this article will contribute to a renaissance of the application of quantitative methods, particularly spatial interaction modelling of the current state of retail facilities and prognosis of their development (see Johnston, 2008).

Before we formulate the research questions, the basic geographical background of the issue under consideration should be provided (Fig. 1 - see cover

\footnotetext{
1 The Oxford Dictionaries defines 'footfall' as "the number of people entering a shop or shopping area in a given time" (http:// oxforddictionaries.com/definition/english/footfall)
} 
p. 2). The city of Olomouc is a mezzo-regional centre in central Moravia and has 100,000 inhabitants. Currently there are four general shopping centres in Olomouc. A shopping centre for our purpose is understood as a group of retail shops including a hypermarket or a supermarket, restaurants and other businesses (we are not taking into account specialised hobby or furniture centres). The oldest one, Prior, is located in the medieval core of the city and was completed in 1982; presently it is under reconstruction. The remaining three shopping centres were constructed during the first half of the 2000s (Obchodní centrum Haná opened in 2002, Olympia in 2004 and Olomouc City in 2005), all in peripheral locations (Olympia closely outside the city cadastre). In February 2012, construction of a fifth shopping centre - Galerie Šantovka - was launched in close vicinity to the historical core of Olomouc. It is to be opened in the autumn of 2013 .

Respecting the assumption that we examine intraurban interactions, not taking into account the hinterland of the city of Olomouc, this starting situation raises the following research questions (the last one being rather theoretical) to which we attempt to seek answers in this contribution:

1. What is the current modelled footfall of the existing shopping centres?, and what spatial patterns do the intra-urban retail-based flows follow?;

2. How will the completion of the Galerie Šantovka shopping centre affect the footfall of the already existing shopping centres?, and how will the spatial patterns of intra-urban retail-based flows change?; and

3. What would have to be the hypothetical size of the existing shopping centres so that their modelled footfall would equal that of the Galerie Šantovka shopping centre?

\section{Spatial interaction modelling}

The theoretical background and historical development of spatial interaction modelling is comprehensively discussed in the research literature, for example by Sheppard (1978), Senior (1979), Haynes, Fotheringham (1984), Fotheringham, O’Kelly (1989), Pooler (1994), Fotheringham, Brunsdon, Charlton (2000), and Wilson (2010), but we provide a basic insight into spatial interaction modelling approaches. In our argumentation, we aim only at cornerstone references specific for the issue (modelling of retail) and the territory (Czech Republic) dealt with in the paper. The modelling of different flows and movements in human geography and regional science was inspired by physical relations (Newton's law of universal gravitation), and appeared already by the end of the $19^{\text {th }}$ century (Ravenstein, 1885).
Models of spatial interactions were further developed by Reilly (1931), who defined the law of retail gravitation. The 1940s saw the development of the approach called social physics (e.g. Zipf, 1947; Stewart, 1948) with an equivalence of demographic force to gravitation force. This conception of spatial interaction modelling led to the formulation of gravity models in their simple "Newtonian" variant (e.g. Isard, 1960; Haggett, 1965; Chojnicki [ed.], 1977). In the Czech lands and Slovakia, such a simple approach was applied by several researchers, e.g. Řehák (2004), Halás (2005), Hubáčková and Krejčí (2007), Řehák, Halás, Klapka (2009) or Halás and Klapka (2010).

While the preceding discussion dwelled on Newtonian physics, most of the following enhancements pursue findings from probability theory or information theory, and employ optimisation procedures with reference to objective functions. An early advance in the theoretical base of spatial interaction modelling was reached in studies published by Wilson (1967, 1974), who was inspired by the second law of thermodynamics and defined a "family" of spatial interaction models that were based on entropy maximisation. Such models seek a most probable situation (i.e. the interaction pattern of origin-destination flows) in a system consisting of equal categories by identifying a macrostate consisting of the largest number of microstates (see Fotheringham, Brunsdon, Charlton, 2000:218). The introduction of a system of constraints into the abovementioned situation produces four types of spatial interaction models (Wilson, 1974). Slightly different ways of deriving the family of spatial interaction models were proposed by Alonso (1978) on the basis of the theory of movement, and by Tobler (1983).

Apart from entropy maximisation, a more general approach based on information minimisation was put forward by Snickars, Weibull (1977) and later applied for example by Plane (1982). It seeks a most probable situation in the system consisting of unequal categories by identifying a minimum information gain (Fotheringham, O'Kelly, 1989:19) as conceived by information theory.

So far the bases for the models have come from physics. In order to address criticisms levelled at such models, particularly that they are still not taking into account the nature of human behaviour, a framework using more behavioural spatial approaches was put forward by Fotheringham, 1986 (see also Fotheringham, O'Kelly, (1989); Fotheringham, Brunsdon, Charlton, (2000)). These models are based on the issue of discrete spatial choice by individuals with respect to the potential alternatives, and on the hierarchical processing of information. Some of the advanced bases 
of spatial interaction models, namely those employing entropy maximisation, were theoretically discussed in Czech and Slovak geography by Paulov (1991) and Hlavička (1993), and applied by Bezák (2000).

Recent developments have brought several new impulses to the theory and context of spatial interaction modelling, with inspirations from economic, ecological, mathematical or behavioural concepts (see more in Wilson, 2010). Openshaw (1998) and particularly Fischer (1998, 2009), or Fischer, Reismann (2002), introduce discussion of the neural network modelling of unconstrained and singly constrained spatial interactions, which dwells on the previous bases of the families of spatial interaction models. Chen (2009) uses a new cross-correlation function in the traditional model that incorporates a time dimension into the modelling. The changing role of distance in the age of the Internet is handled for instance by Blum, Goldfarb (2006).

A number of relatively recent works is concerned with the joint problem of intervening opportunity, spatial discrete choice and probability of choice. For instance, Akwawua and Pooler (2001) introduced spatial dominance effects that combine the size and distance of destinations into the intervening opportunity scheme. Drezner, Drezner (2007) discuss a p-median problem dealing with the customers' choice of destinations.

The application of spatial interaction models in retailing studies goes back to works published by Reilly (1931), who defined the relation between two competing centres and an intervening location based on retail commuting. His work was extended by Converse (1949) and Huff (1964). Converse (1949) defined mathematically the breaking point between the influences of competing centres, and Huff (1964) expressed a theoretical probability of customer choice from shopping centres. He proposed a model that is able to estimate footfall in a particular shopping centre taking into account the selling areas of shopping centres and the time distance between customers and shopping centres. Fotheringham (1985, 2012 - first published in 1989) considers the estimation of shopping trips and their spatial distribution as a classic spatial interaction modelling task.

Spatial interaction models have been recently applied in various forms to a wider area of retail research, for instance by Lee, Pace (2005) who modelled the spatial distribution of retail turnover between shopping centres. Schenk et al. (2007) dealt with the modelling of consumer behaviour in terms of grocery shopping on a regional level in the functional region of Umeå, Sweden. Suárez-Vega et al. (2007) defined the attraction function between a shopping facility and customers. Li,
Liu (2012) assessed the performance of shopping malls based on their location by employing a modified version of Huff's model. Scott, He (2012) introduced a timegeographical approach to the shopping destination choice model. Rasouli, Timmermans (2013) enriched the problem with the issue of uncertainty in shopping behaviour, which affects the application and form of spatial interaction models.

Spatial interaction models generally show that the volume of spatial interaction increases with scale (i.e. either quantitative or qualitative "importance" "size", or "mass") of locations, and decreases with the distance separating them. To put it another way, the interaction $\left(T_{i j}\right)$ between two location $i$ and $j$ is a function of the measure $\mathrm{v}$ of propulsiveness of $i$, the measure $w$ of attractiveness of $j$, and the measure $d$ of distance between $i$ and $j$ :

$$
T_{i j}=f\left(\mu v_{i} ; \alpha w_{j} ; \beta d_{i j}\right)
$$

where $\mu, \alpha, \beta$ are parameters reflecting the relation of variables $v, w$ and $d$ to the interaction patterns. The greatest importance is granted to the variable and parameter responsible for the formulation of the friction of distance and its expression in the models. The spatial separation between two spatial locations is expressed in the form of distance decay curves that have various forms and usually a nonlinear shape (e.g. Taylor, 1971, 1983; Johnston, 1973; Wilson, 1974, or Sheppard, 1978). Negative Pareto and negative exponential functions with various values of parameters have been applied most frequently to express the spatial separation between two locations. The role of distance and the distance decay function is discussed for instance by Taylor (1971), Cliff et al. (1974), Wilson (1974), Fotheringham (1981), and De Vries et al. (2009).

\section{Method}

\subsection{The form of the model}

The family of spatial interaction models (or in our case gravity models) consists basically of four variants: unconstrained case, production-constrained case, attraction-constrained case and productionattraction (or doubly) constrained case (Wilson, 1974; Fotheringham, O'Kelly, 1989). For our purpose, when we investigate the footfall of shopping centres, the production-constrained variant of the model provides the greatest advantage (see, for example, the numerous applications listed in Fotheringham, 1986; Fotheringham, O'Kelly, 1989, or Wilson, 2010). To put it short at first, the model seeks a spatial pattern for the allocation of retail flows (shopping trips) from residential zones to shopping centres, assuming that 
we have a prior knowledge of a number of these outgoing flows. This knowledge acts as a production constraint and can be expressed as follows:

$$
\mathrm{O}_{i}=\sum_{j} T_{i j}
$$

where $O_{i}$ stands for the total of outgoing flows from $i$.

Taking into account this constraint [2], the model can be formally expressed as:

$$
T_{i j}=A_{i} \mathrm{O}_{i} w_{j} d_{i j}^{-\beta}
$$

where:

$T_{i j}$ expresses the volume of interaction between $i$ and $j$; $A_{i}$ plays the role of a balance parameter; $O_{i}$ expresses the number of outflows from origins; $w_{j}$ plays the role of a proxy variable expressing the attractiveness of destinations; $d_{i j}$ marks a distance between $i$ and $j$; and $\beta$ is a parameter of the model controlling the shape of the distance decay function.

The balance parameter $A_{i}$ ensures that on the demand (i.e. production) side of the model, the number of total outflows from origins is exactly reproduced by the model and allocated to destinations; in our case, that the number of outgoing shopping trips from the residential zones is totally distributed among the shopping centres on the supply (i.e. attraction) side of the model. The balance parameter is expressed as follows, using the above symbols:

$$
A_{i}=\left(\sum_{j} w_{j} d_{i j}^{-\beta}\right)^{-1}
$$

If a mathematical expression should be used, the balance parameter $A_{i}$ ensures that the constraint given by equation [2], for this purpose written preferably in reverse order as

$$
\sum_{j} T_{i j}{ }^{*}=\mathrm{O}_{i}
$$

is fulfilled in the matrix of estimated flows, the asterisk denoting then, that in this case, $T_{i j}$ stands for the estimated flow between $i$ and $j$.

\subsection{Variables entering the model}

In this section, we will specify the character of the data entering the model. The origins $i$ are related to the basic settlement units - BSUs (see Figs. 1 (cover p. 2) or 2) - which are the smallest spatial zones for the used data gathered from the 2001 census. These are the numbers of independent households (see Tab. 2), since we assume that shopping trips are usually made for the whole household. Another approximation should be made with respect to the location of basic settlement

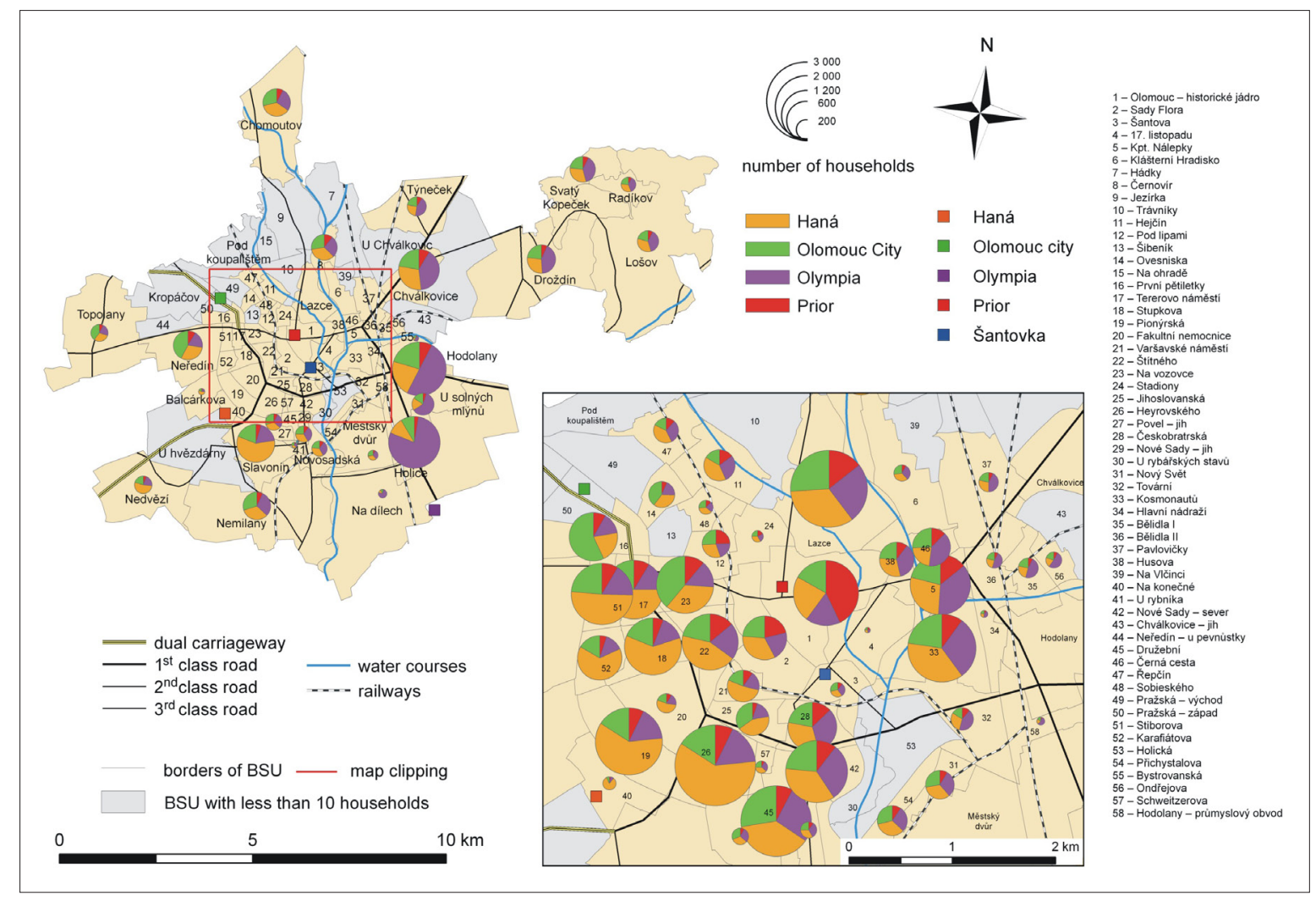

Fig. 2: Modelled footfall of the four currently existing shopping centres Sources: 2001 Population census, Authors' elaboration 
units. They are of areal character and if we calculate distances $\left(d_{i j}\right)$ between origins and destinations, we have to deploy a point pattern for both variables, in our case based on the public transport stops (see below for the nature of the distance measure used). While this nature is inherent to shopping centres, we have used the geographic centres of built-up areas within each areal unit and the nearest public transport stop to the centres, in order to acquire a point pattern of origins (see e.g. Fig. 2). Out of 82 basic settlement units in the city of Olomouc, sixteen (see e.g. Fig. 2 grey colour) have less than 10 (in seven cases zero) independent households and these have been excluded from the analysis. Thus, 66 basic settlement units were finally entered into the interaction and spatial separation matrices.

Four (and later five) shopping centres are destinationsj, thus constituting the columns of the interaction and spatial separation matrices. Since we have no prior knowledge of ingoing flows to the shopping centres, we have to express their attractiveness by a proxy variable $w$.

Our case should rather be called a pseudo-productionconstrained variant, regarding the character of the data, where we know the number of flows originating in the spatial zones (in this case the BSUs), while the attractiveness of the shopping centres has to be expressed by a proxy variable. In this respect, we have made use of the selling areas of the shopping centres (Tab. 1).

\begin{tabular}{|l|c|}
\hline \multicolumn{1}{|c|}{ Shopping centre } & Selling area $\left(\mathbf{m}^{\mathbf{2}}\right)$ \\
\hline Obchodní centrum Haná & 37,500 \\
\hline Olympia & 30,000 \\
\hline Olomouc City & 24,500 \\
\hline Prior & 5,000 \\
\hline Galerie Šantovka & $46,500^{*}$ \\
\hline
\end{tabular}

Tab. 1: Selling areas of shopping centres

Note: *planned selling area

Source: Internet pages of retail chains, Szczyrba, 2010
The last variable entering the model is the distance between origins and destinations. We have tested three types of distance (Euclidian distance, time distance by automobile, and time distance by public transport), and the results provided by the time distance by public transport are presented in this article. Although the presentation of all results is not possible due to size constraints, our choice needs to be justified. The Euclidian distance has served the principal methodological purpose as a common basis for comparisons of the results provided by both types of time distances. Finally, we have resorted to the time distance by public transport as we have preferred the transport mode that is accessible virtually to anyone and that provides a more stable expression of distance based on timetables. The last issue to be discussed is the distance decay function. We have used the negative power function and tested four values of the $\beta$ parameter expressing the resistance of distance to the interactions. Haynes, Fotheringham (1984) claim that the $\beta$ parameter is often empirically found between ( -0.5 and -2.0 ), and Fotheringham, Brunsdon, Charlton (2000:232) suggest a power function with the value of the $\beta$ parameter $=(-1)$ for the assessment of competing alternatives in a spatial choice problem such as this. In accord with these findings, we have set the $\beta$ parameter to $(-1)$.

\section{Results of the modelling}

In the following discussion, we aim particularly at textual presentation of the general results regarding the modelled flow and predicted footfall of the shopping centres. The fine network of modelled intra-urban flows between the shopping centres and basic settlement units is not commented upon since it can be sufficiently understood from Figs. 2, 3, 4, and Tab. 4 providing necessary data and their spatial representation.

\subsection{Starting situation}

Detailed results provided by the productionconstrained gravity model for the existing four shopping centres (Prior, Olympia, Haná and City) are presented in Fig. 2 and Tabs. 2 and 4 recording the modelled situation. Fig. 2 and Tab. 4 show the current

\begin{tabular}{|l|c|c|c|}
\hline \multicolumn{1}{|c|}{ Shopping centre } & No. of households per $\mathbf{~}^{\mathbf{2}}$ & $\begin{array}{c}\text { Percentage out of total } \\
\text { selling area }\end{array}$ & $\begin{array}{c}\text { Percentage of attracted } \\
\text { households out of total }\end{array}$ \\
\hline Obchodní centrum Haná & 0.45 & 38.7 & 39.2 \\
\hline Olympia & 0.39 & 31.0 & 26.5 \\
\hline Olomouc City & 0.42 & 25.2 & 23.2 \\
\hline Prior & 0.97 & 5.1 & 11.1 \\
\hline
\end{tabular}

Tab. 2: General modelled situation (4 shopping centres)

Sources: Internet pages of retail chains, Szczyrba 2010, Authors' calculations 


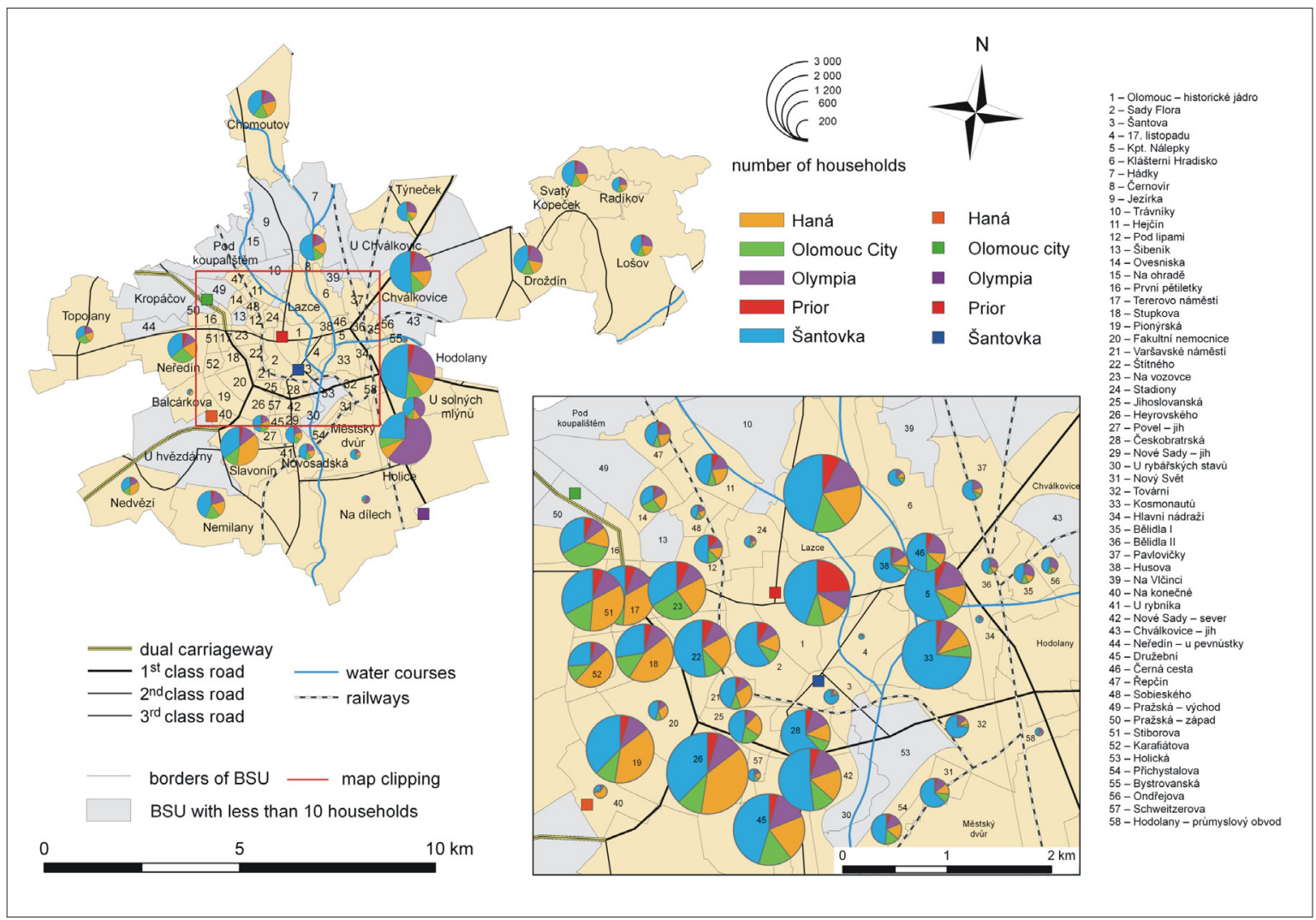

Fig. 3: Modelled footfall of the five future shopping centres

Sources: 2001 population census, Authors' elaboration

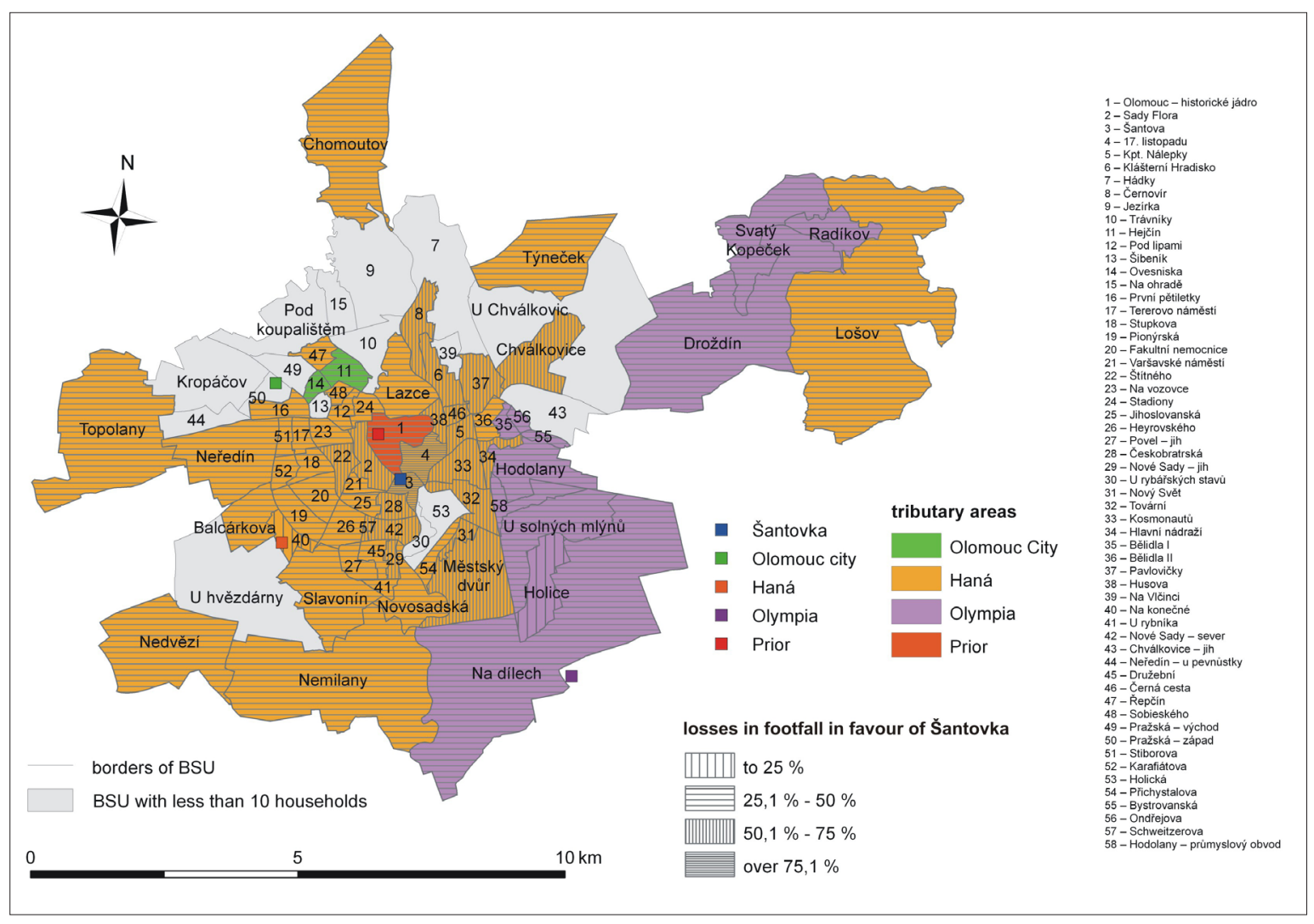

Fig. 4: Construction of the Galerie Šantovka and its influence on the footfall spatial pattern Sources: 2001 Population census, Authors 'elaboration 
modelled relations of households within each BSU to the existing shopping centres, or, in other words, the modelled distribution of households among the shopping centres, which can be understood herein as the expression of modelled spatial shopping preferences of the Olomouc city population.

In general, the model shows that out of 43,603 households in Olomouc, the highest percentage is attracted by the Obchodní centrum Haná $(39.2 \%$ of households) followed by Olympia (26.5\%), Olomouc City $(23.2 \%)$ and Prior (11.1\%) - see Tab. 2. This general pattern correlates with the total selling area share of the shopping centres (Tab. 2), though this relation is not linear, since the location of the shopping centres and the time distance between BSUs and the shopping centres play an important role in this respect.

However, if we take into account the number of attracted households per one square metre (Tab. 2), the most successful facility is Prior $\left(0.97\right.$ households $\left./ \mathrm{m}^{2}\right)$, given its position in the centre. The lowest number is recorded for Olympia ( 0.39 households $\left./ \mathrm{m}^{2}\right)$, which is located outside the city cadastre. Nevertheless, the remaining two shopping centres (Haná and City) do not significantly differ from the Olympia in the number of households per square metre and thus we identify two types of shopping centres: newly-constructed suburban facilities and traditional centrally-located facilities.

\subsection{Situation after the completion of the Galerie Šantovka}

Detailed results of the modelled prediction concerning the situation after the opening of the Galerie Šantovka are presented in Figs. 3, 4 and Tabs. 3 and 4. Fig. 3 and Tab. 4 show a prediction of the spatial distribution of households among the future five shopping centres, and thus can be understood as a modelled prediction of the future spatial shopping preferences of residents in the city of Olomouc.

These preferences are assumed to turn dramatically in favour of the newly-constructed Galerie Šantovka, since it will attract $44.9 \%$ out of 43,603 households in
Olomouc. The present leader, Obchodní centrum Haná, will attract $22.1 \%$ of households, and will be followed by Olympia (14.3\%), Olomouc City (12.8\%) and Prior (5.9\%) - see Tab. 3. The correlation between the share of the shopping centres in the total selling area and the percentage of attracted households is slightly lower than in the case of the original four shopping centres, but still significant. This lower value is caused by the specific conditions of the Galerie Šantovka - it will be the largest shopping centre in Olomouc and it will be located in the centre, which will change the existing spatial patterns.

The number of attracted households per one square meter (Tab. 3) illustrates the position of Prior ( 0.51 households/ $\mathrm{m}^{2}$ ) in spite of the fact that this facility experiences the highest decrease in this parameter. The three suburban shopping centres (Olympia, Olomouc City and Obchodní centrum Haná) have comparable numbers, thus showing their affinity to the newly-constructed facility type. The Galerie Šantovka $\left(0.42\right.$ households $\left./ \mathrm{m}^{2}\right)$ represents the third facility type: a relatively centrally-located revitalised brownfield. The lower number of attracted households per one square meter as compared with Prior indicates a more spacious conception of the $21^{\text {st }}$ century shopping centre as opposed to the 1970s concept of the socialist shopping facility.

Following the completion of the Galerie Šantovka, all existing shopping centres are expected to lose more than one half of the attracted households according to the production-constrained gravity model (Obchodní centrum Haná 56.6\%, Olomouc City 55.1\%, Olympia 53.9\% and Prior 53.1\%). The spatial distribution of this phenomenon is presented in Fig. 4, together with the original tributary areas of the four existing centres delineated according to the first (highest) outflow from each BSU. These tributary areas show the present importance of the Obchodní Centrum Haná shopping centre and its favourable location within the public transport network. It is the only shopping centre with a tram connection, considerably increasing its accessibility (it is useful to remember that time

\begin{tabular}{|l|c|c|c|}
\hline \multicolumn{1}{|c|}{ Shopping centre } & No. of households per $\mathbf{~}^{\mathbf{2}}$ & $\begin{array}{c}\text { Percentage out of total } \\
\text { selling area }\end{array}$ & $\begin{array}{c}\text { Percentage of attracted } \\
\text { households out of total }\end{array}$ \\
\hline Galerie Šantovka* & 0.42 & 32.4 & 44.9 \\
\hline Obchodní centrum Haná & 0.26 & 26.1 & 22.1 \\
\hline Olympia & 0.21 & 20.9 & 14.3 \\
\hline Olomouc City & 0.23 & 17.1 & 12.8 \\
\hline Prior & 0.51 & 3.5 & 5.9 \\
\hline
\end{tabular}

Tab. 3: General modelled situation (5 shopping centres)

Note: *data for the planned selling area

Sources: Internet pages of retail chains, Szczyrba 2010, Authors' calculations 


\begin{tabular}{|c|c|c|c|c|c|c|c|c|c|c|c|}
\hline \multirow{2}{*}{ Name of BSU } & \multirow{2}{*}{$\begin{array}{l}\frac{n}{0} \\
0 \\
0 \\
0 \\
0 \\
0 \\
0 \\
0\end{array}$} & \multicolumn{2}{|c|}{ Prior } & \multicolumn{2}{|c|}{ Olympia } & \multicolumn{2}{|c|}{ Haná } & \multicolumn{2}{|c|}{ City } & \multirow{2}{*}{ 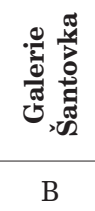 } & \multirow{2}{*}{ 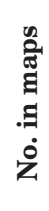 } \\
\hline & & A & B & A & B & A & $\mathrm{B}$ & A & B & & \\
\hline 17, listopadu & 14 & 3.1 & 0.6 & 3.5 & 0.7 & 4.0 & 0.8 & 3.4 & 0.7 & 11.3 & 4 \\
\hline Balcárkova & 18 & 1.3 & 0.8 & 3.2 & 1.9 & 10.4 & 6.3 & 3.1 & 1.9 & 7.1 & - \\
\hline Bělidla I & 183 & 13.4 & 7.2 & 86.0 & 46.5 & 44.3 & 23.9 & 39.3 & 21.3 & 84.1 & 35 \\
\hline Bělidla II & 118 & 8.6 & 4.7 & 55.5 & 30.0 & 28.5 & 15.4 & 25.4 & 13.7 & 54.2 & 36 \\
\hline Bystrovanská & 14 & 1.1 & 0.6 & 7.3 & 4.1 & 2.8 & 1.5 & 2.8 & 1.6 & 6.3 & 55 \\
\hline Černá cesta & 672 & 83.2 & 41.1 & 266.1 & 131.5 & 151.2 & 74.7 & 171.6 & 84.8 & 339.8 & 46 \\
\hline Černovír & 312 & 33.3 & 16.0 & 82.6 & 39.7 & 111.0 & 53.3 & 85.1 & 40.9 & 162.2 & 8 \\
\hline Českobratrská & 1,121 & 145.0 & 55.7 & 366.3 & 140.7 & 362.5 & 139.2 & 247.1 & 94.9 & 690.5 & 28 \\
\hline Droždín & 381 & 24.5 & 14.2 & 161.3 & 93.5 & 105.9 & 61.4 & 89.3 & 51.7 & 160.2 & - \\
\hline Družební & 2,337 & 178.3 & 97.5 & 623.9 & 341.4 & 891.3 & 487.7 & 643.6 & 352.2 & $1,058.3$ & 45 \\
\hline Fakultní nemocnice & 175 & 15.5 & 8.5 & 32.4 & 17.8 & 93.2 & 51.1 & 33.8 & 18.5 & 79.1 & 20 \\
\hline Hejčín & 457 & 67.5 & 36.6 & 129.7 & 70.2 & 184.2 & 99.8 & 75.6 & 41.0 & 209.4 & 11 \\
\hline Heyrovského & 3,062 & 220.4 & 137.5 & 495.9 & 309.5 & $1,859.7$ & $1,160.5$ & 486.0 & 303.3 & $1,151.2$ & 26 \\
\hline Hlavní nádraží & 23 & 2.6 & 0.8 & 9.3 & 2.6 & 6.0 & 1.7 & 5.0 & 1.4 & 16.4 & 34 \\
\hline Hodolany & 1,353 & 103.1 & 53.0 & 674.9 & 347.0 & 299.4 & 153.9 & 275.6 & 141.7 & 657.4 & - \\
\hline Hodolany průmyslový obvod & 29 & 1.7 & 0.9 & 16.7 & 9.3 & 6.1 & 3.4 & 4.5 & 2.5 & 12.9 & 58 \\
\hline Holice & 1,252 & 31.2 & 23.6 & 984.1 & 742.8 & 129.5 & 97.7 & 107.2 & 80.9 & 307.0 & - \\
\hline Husova & 559 & 57.3 & 19.7 & 202.4 & 69.6 & 165.4 & 56.9 & 133.8 & 46.0 & 366.8 & 38 \\
\hline Chomoutov & 356 & 27.6 & 16.6 & 95.8 & 57.7 & 130.0 & 78.3 & 102.5 & 61.8 & 141.6 & - \\
\hline Chválkovice & 777 & 66.5 & 32.6 & 308.3 & 151.1 & 229.1 & 112.3 & 173.1 & 84.8 & 396.3 & - \\
\hline Jihoslovanská & 501 & 23.8 & 12.6 & 88.5 & 47.0 & 214.0 & 113.7 & 174.7 & 92.8 & 234.9 & 25 \\
\hline Karafiátova & 929 & 47.2 & 34.8 & 121.3 & 89.6 & 606.5 & 447.9 & 154.1 & 113.8 & 243.0 & 52 \\
\hline Klášterní Hradisko & 123 & 10.3 & 3.7 & 36.6 & 13.2 & 42.6 & 15.3 & 33.6 & 12.1 & 78.7 & 6 \\
\hline Kosmonautů & 2,179 & 217.6 & 57.5 & 652.9 & 172.4 & 816.2 & 215.5 & 492.2 & 130.0 & $1,603.6$ & 33 \\
\hline Kpt. Nálepky & 1,703 & 243.4 & 104.5 & 625.8 & 268.7 & 476.1 & 204.4 & 357.7 & 153.6 & 971.8 & 5 \\
\hline Lazce & 2,779 & 400.3 & 216.1 & 700.6 & 378.2 & 955.4 & 515.7 & 722.7 & 390.1 & $1,278.9$ & - \\
\hline Lošov & 210 & 15.5 & 8.9 & 79.8 & 46.1 & 70.4 & 40.7 & 44.3 & 25.6 & 88.7 & - \\
\hline Městský dvůr & 48 & 3.6 & 1.6 & 15.1 & 6.6 & 16.1 & 7.0 & 13.2 & 5.8 & 27.0 & - \\
\hline Na dílech & 30 & 0.9 & 0.7 & 22.4 & 16.4 & 4.2 & 3.1 & 2.4 & 1.8 & 8.0 & - \\
\hline Na konečné & 81 & 2.4 & 1.9 & 6.1 & 4.8 & 66.5 & 52.1 & 5.9 & 4.6 & 17.6 & 40 \\
\hline Na vozovce & 1,530 & 170.2 & 112.2 & 232.1 & 153.0 & 531.9 & 350.6 & 595.8 & 392.6 & 521.6 & 23 \\
\hline Nedvězí & 144 & 8.9 & 5.8 & 29.4 & 19.0 & 75.9 & 49.1 & 29.8 & 19.3 & 50.8 & - \\
\hline Nemilany & 355 & 24.6 & 13.8 & 106.0 & 59.6 & 117.8 & 66.2 & 106.6 & 59.9 & 155.5 & - \\
\hline Neředín & 394 & 33.9 & 21.6 & 72.7 & 46.2 & 121.2 & 77.1 & 166.2 & 105.7 & 143.4 & - \\
\hline Nové Sady-jih & 123 & 12.0 & 5.8 & 38.9 & 18.8 & 41.7 & 20.1 & 30.5 & 14.7 & 63.6 & 29 \\
\hline Nové Sady-sever & 1,800 & 189.6 & 90.8 & 541.7 & 259.4 & 646.4 & 309.5 & 422.3 & 202.2 & 938.1 & 42 \\
\hline
\end{tabular}

Tab. 4: Modelled footfall of the shopping centres with respect to the number of households in basic settlement units Note: A - situation with 4 shopping centres, $B$ - situation with 5 shopping centres

Sources: 2001 Population census, Authors' calculations 
Tab. 4: continuance from previous page

\begin{tabular}{|c|c|c|c|c|c|c|c|c|c|c|c|}
\hline \multirow{2}{*}{ Name of BSU } & \multirow{2}{*}{$\begin{array}{l}\frac{y}{0} \\
0 \\
0 \\
0 \\
0 \\
0 \\
0 \\
0\end{array}$} & \multicolumn{2}{|c|}{ Prior } & \multicolumn{2}{|c|}{ Olympia } & \multicolumn{2}{|c|}{ Haná } & \multicolumn{2}{|c|}{ City } & \multirow{2}{*}{ 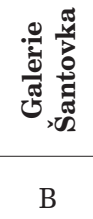 } & \multirow{2}{*}{ 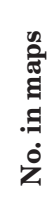 } \\
\hline & & $\mathrm{A}$ & B & $\mathrm{A}$ & $\mathrm{B}$ & $\mathrm{A}$ & B & $\mathrm{A}$ & B & & \\
\hline Novosadská & 112 & 10.5 & 5.4 & 36.4 & 18.8 & 39.4 & 20.4 & 25.7 & 13.3 & 54.1 & - \\
\hline Nový svět & 384 & 33.3 & 12.2 & 115.2 & 42.2 & 129.1 & 47.3 & 106.4 & 39.0 & 243.2 & 31 \\
\hline Olomouc-historické jádro & 1,988 & 854.1 & 474.7 & 341.6 & 189.9 & 457.5 & 254.3 & 334.8 & 186.1 & 883.0 & 1 \\
\hline Ondřejova & 119 & 9.2 & 5.1 & 62.5 & 34.4 & 23.4 & 12.9 & 23.9 & 13.2 & 53.4 & 56 \\
\hline Ovesniska & 318 & 20.7 & 13.7 & 60.0 & 39.9 & 110.7 & 73.6 & 126.6 & 84.2 & 106.5 & 14 \\
\hline Pavlovičky & 176 & 13.2 & 5.5 & 74.7 & 31.2 & 49.6 & 20.7 & 38.4 & 16.0 & 102.6 & 37 \\
\hline Pionýrská & 2,101 & 151.2 & 94.4 & 340.3 & 212.3 & $1,276.0$ & 796.3 & 333.5 & 208.1 & 789.9 & 19 \\
\hline Pod lipami & 357 & 88.1 & 44.4 & 72.1 & 36.3 & 104.3 & 52.6 & 92.5 & 46.6 & 177.0 & 12 \\
\hline Povel-jih & 129 & 10.2 & 5.3 & 36.8 & 19.1 & 42.5 & 22.2 & 39.5 & 20.6 & 61.8 & 27 \\
\hline První pětiletky & 1,097 & 91.1 & 61.1 & 153.1 & 102.6 & 227.8 & 152.7 & 625.0 & 419.1 & 361.5 & 16 \\
\hline Přichystalova & 419 & 39.8 & 20.3 & 114.9 & 58.7 & 143.6 & 73.4 & 120.7 & 61.7 & 204.8 & 54 \\
\hline Radíkov & 102 & 7.3 & 4.1 & 37.7 & 21.3 & 33.0 & 18.6 & 24.0 & 13.5 & 44.4 & - \\
\hline Řepčín & 289 & 33.7 & 18.8 & 89.0 & 49.6 & 115.9 & 64.5 & 50.5 & 28.1 & 128.0 & 47 \\
\hline Sady Flora & 910 & 192.1 & 77.7 & 192.1 & 77.7 & 308.7 & 124.9 & 217.2 & 87.9 & 541.9 & 2 \\
\hline Schweitzerova & 70 & 5.8 & 2.9 & 18.9 & 9.3 & 27.4 & 13.5 & 17.9 & 8.8 & 35.4 & 57 \\
\hline Slavonín & 675 & 30.9 & 19.9 & 121.3 & 77.9 & 394.1 & 253.1 & 128.7 & 82.7 & 241.4 & - \\
\hline Sobieského & 94 & 11.5 & 6.4 & 22.0 & 12.2 & 35.7 & 19.8 & 24.8 & 13.8 & 41.8 & 48 \\
\hline Stadiony & 61 & 10.7 & 5.6 & 14.6 & 7.7 & 20.1 & 10.5 & 15.5 & 8.1 & 29.1 & 24 \\
\hline Stiborova & 1,774 & 150.3 & 101.2 & 300.7 & 202.5 & 902.0 & 607.4 & 420.9 & 283.5 & 579.4 & 51 \\
\hline Stupkova & 1,528 & 90.7 & 65.8 & 213.9 & 155.0 & 935.7 & 678.2 & 287.7 & 208.5 & 420.5 & 18 \\
\hline Svatý Kopeček & 305 & 23.2 & 12.6 & 116.1 & 63.0 & 94.6 & 51.4 & 71.1 & 38.6 & 139.5 & - \\
\hline Šantova & 98 & 10.6 & 2.1 & 28.2 & 5.6 & 31.7 & 6.3 & 27.6 & 5.5 & 78.4 & 3 \\
\hline Štítného & 1,482 & 207.1 & 99.4 & 310.6 & 149.1 & 647.2 & 310.7 & 317.1 & 152.2 & 770.5 & 22 \\
\hline Tererovo náměstí & 1,616 & 137.9 & 92.6 & 264.7 & 177.9 & 827.3 & 555.9 & 386.1 & 259.4 & 530.2 & 17 \\
\hline Topolany & 135 & 10.2 & 6.8 & 29.9 & 19.8 & 41.8 & 27.8 & 53.1 & 35.2 & 45.4 & - \\
\hline Tovární & 236 & 27.0 & 7.2 & 100.4 & 26.6 & 71.2 & 18.9 & 37.4 & 9.9 & 173.4 & 32 \\
\hline Týneček & 172 & 15.4 & 7.8 & 74.6 & 37.9 & 43.3 & 22.0 & 38.7 & 19.6 & 84.8 & - \\
\hline U rybníka & 15 & 1.2 & 0.6 & 4.5 & 2.4 & 5.3 & 2.8 & 4.0 & 2.1 & 7.1 & 41 \\
\hline U solných mlýnů & 226 & 10.9 & 6.6 & 138.4 & 84.8 & 41.9 & 25.7 & 34.8 & 21.3 & 87.6 & - \\
\hline Varšavské náměstí & 473 & 47.0 & 26.0 & 89.7 & 49.6 & 246.7 & 136.4 & 89.6 & 49.5 & 211.5 & 21 \\
\hline Total & 43,603 & 4,834 & 2,567 & 11,550 & 6,222 & 17,045 & 9,643 & 10,173 & 5,606 & 19,565 & - \\
\hline
\end{tabular}

distances entering the model were public transport time distances, which made the content of Fig. 4 somewhat unexpected; results based on Euclidean distance or automobile time distance would provide considerably different tributary areas of the shopping centres).

\subsection{Hypothetical size of the existing shopping centres}

The gravity model is also able to infer a hypothetical situation that provides an answer to the third research question raised in the introduction. Table 5 presents theoretical selling areas of the existing shopping centres that would generate the same footfall (i.e. attraction for the households) as the Galerie Šantovka with its $46,500 \mathrm{~m}^{2}$ of planned selling area. Here we assume that the known demand level is preserved in the computation and that only its spatial distribution is altered. A note should be made here that for each estimated selling area of individual shopping centres, 
the model takes into account the influence of the remaining shopping centres and the Galerie Šantovka itself, and their current (planned) selling areas. Thus, each row in Tab. 5 represents a different situation.

The Prior shopping centre would need the greatest expansion of its selling area as compared with its current size. An 8.5-times larger selling area would attract the same footfall as the model predicts for the
Galerie Šantovka. In absolute figures, Olympia would have to extend its selling area by $71,600 \mathrm{~m}^{2}$ to equal the footfall of the Galerie Santovka. On the other hand, the Obchodní centrum Haná proves its relative competitiveness (shown in Figs. 3 and 4) also in both figures presented in Tab. 5 .

If we venture to take our conjectures even further, we are able to outline the most interesting situations

\begin{tabular}{|l|c|c|c|c|}
\hline \multicolumn{1}{|c|}{ Shopping centre } & Current area $\left.\mathbf{( m}^{\mathbf{2}}\right)$ & Theoretical area $\left.\mathbf{( m}^{\mathbf{2}}\right)$ & Difference $\left(\mathbf{m}^{\mathbf{2}}\right)$ & Multiple \\
\hline Haná & 37,500 & 93,500 & 56,000 & 2.5 \\
\hline Olympia & 30,000 & 101,600 & 71,600 & 3.4 \\
\hline Olomouc city & 24,500 & 95,000 & 70,500 & 3.9 \\
\hline Prior & 5,000 & 42,500 & 37,500 & 8.5 \\
\hline
\end{tabular}

Tab. 5: Hypothetical size of the existing shopping centres matching the footfall of the planned Galerie Šantovka Note: Planned area of Galerie Šantovka is 46,500 $\mathrm{m}^{2}$ Source: Authors' calculations

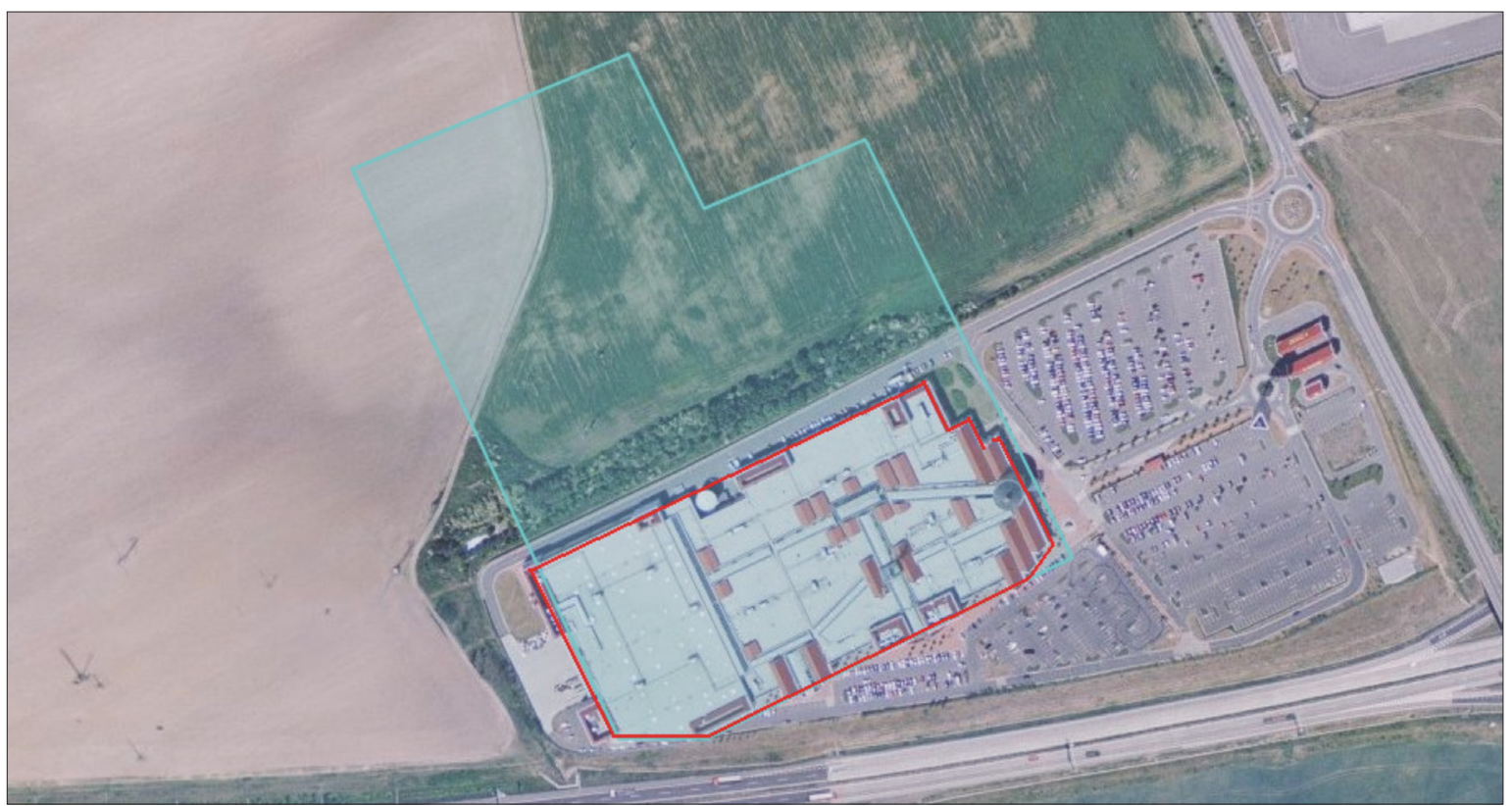

Fig. 5: Example of a hypothetical expansion of the shopping centre (Olympia) with no or little spatial conflicts expected Source: Národní geoportál INSPIRE, Authors' elaboration

in the respective spatial contexts (see Figs. 5, 6a, b and $7 \mathrm{a}, \mathrm{b})$. This time they should be considered as highly hypothetical, with no spatial and municipal planning connotations and ambitions, as they appear mostly infeasible and sometimes even impossible. We present them as one of the interesting results available through spatial interaction modelling.

Fig. 5 presents a hypothetical expansion of Olympia while keeping its current height (i.e. number of floors). This expansion would face little or no spatial conflicts since the Olympia is located at the outskirts of the city of Olomouc with sufficient development areas in its vicinity (mostly arable land). In this case, the expansion of the shopping centre appears generally possible -- but not taking into account numerous other factors, such as broader economic conditions, etc.

On the contrary, the hypothetical expansion of Prior appears impossible in all respects. Fig. 6a, b present two options of the horizontal expansion of Prior while keeping its current height and following the course of important communications. In the first case (Fig. 6a), the UNESCO site of the Holy Trinity Column, the gothic church of St. Moritz and parts of the blocks of medieval and early modern houses, would have 

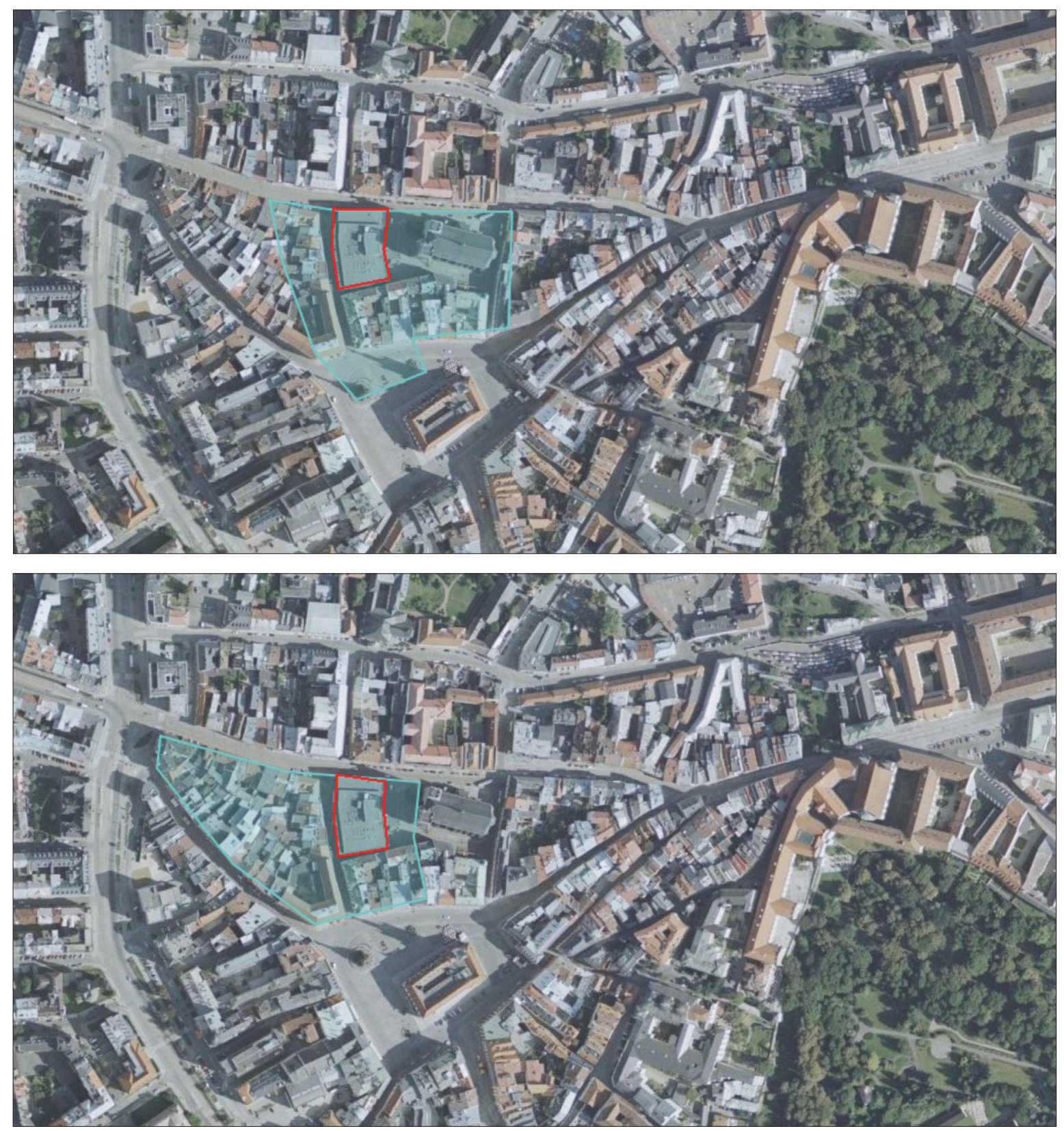

Figs. 6a, b: Examples of a hypothetical horizontal expansion of the shopping centre (Prior) with severe spatial conflicts in the city structure

Source: Národní geoportál INSPIRE, Authors' elaboration

to be destroyed. In the second case (Fig. 6b), the whole large block of predominantly medieval and early modern houses would have to give way to the expansion of Prior.

Another hypothetical possibility would be to keep the current floor projection of Prior and to propose a vertical expansion of the shopping centre. The results of this step (see Figs. 7a, b) would severely disturb not only the townscape of the historical core of Olomouc but also the skyline of the whole city and its surroundings. For comparison, the spire of St. Wenceslas Cathedral (near the upper left corner of Figs. 7a, b) reaches a height of $102 \mathrm{~m}$.

\section{Conclusion}

The application of the production-constrained gravity model has provided sufficient data for the description, prediction and inference of spatial phenomena related to the issue of the shopping centres' footfall in the city of Olomouc, and helped to answer the research questions raised at the outset.

However, reading these results, one has to be aware of two constraints setting the research framework. One of them is the spatial context which excluded the surroundings of the city of Olomouc, which somewhat decreased the total intensity of interactions and the 

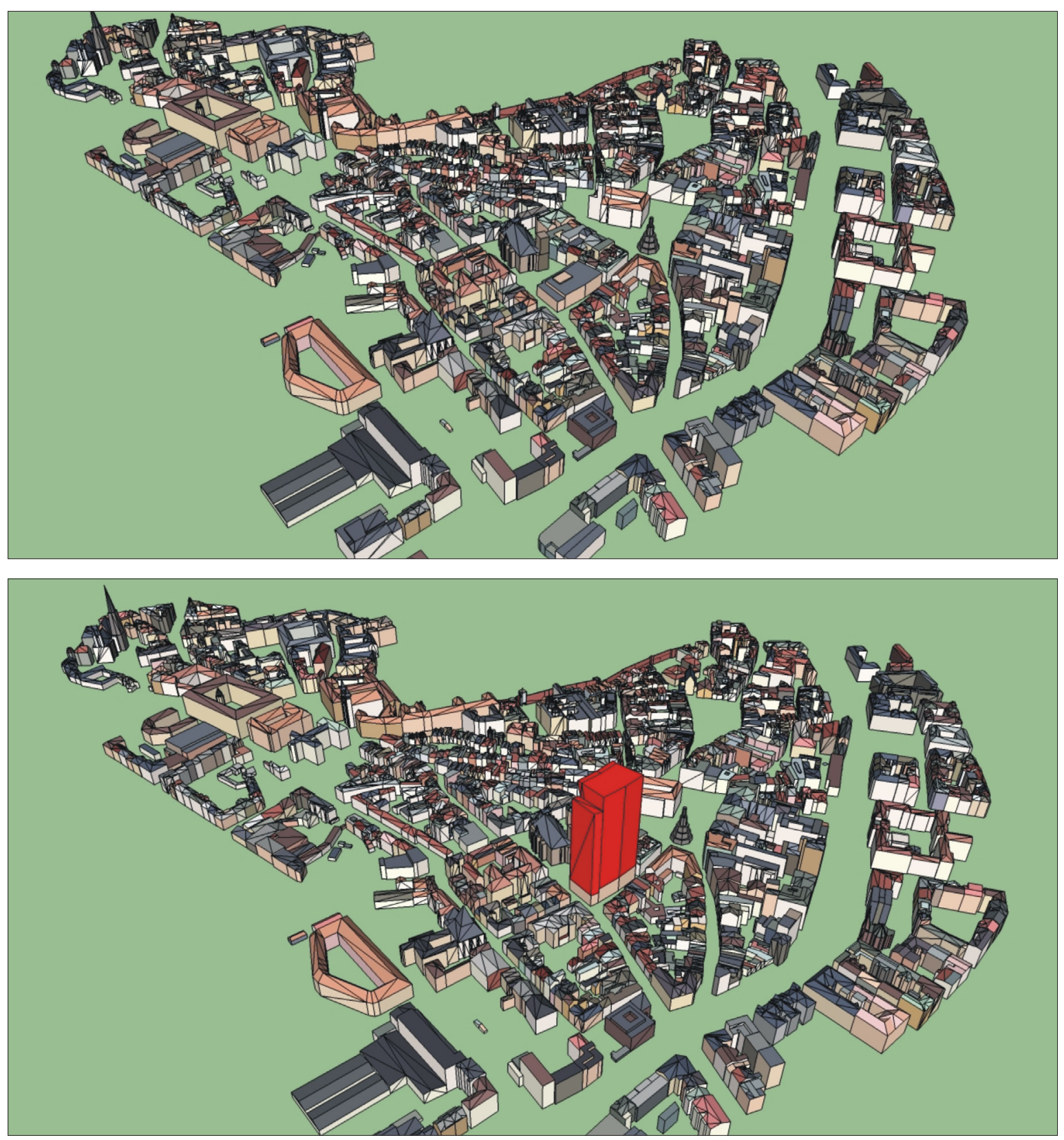

Figs. 7a, b: Example of a hypothetical vertical expansion of the shopping centre (Prior) with severe conflicts in the townscape

Source: Authors' elaboration

modelled footfall of the shopping centres. Secondly, the distance between origins and destinations applied in the model had certain effects on the spatial patterns.

Apart from these disadvantages, inherent to spatial interaction models, the gravity model option applied in our study confirmed the crucial role of location in similar research tasks (i.e. location of shopping centres). Several notions on the location of shopping centres in Olomouc should be presented here. We only hint at some of the related issues hereinafter because they would deserve further detailed individual studies. We rather point out the identifying role of the gravity model. Firstly, the importance of location should be considered more as a relative rather than an absolute measure, since the relative locations of the competing shopping centres, the concentration of households, and the place within the public transport network, have acted as mutually dependent factors creating the modelled spatial patterns.

Secondly, within this relatively conceived system of locations, their central positions within the city have brought the greatest advantages for such retail facilities, which is documented on the examples of Prior (both in the present and predicted states) and Galerie Šantovka (in the predicted state). In spite of having the smallest selling area, Prior would experience the 
smallest relative decrease in footfall upon completion of the Galerie Šantovka. In contrast, the suburban retail facilities, particularly those with poor public transport connections (Olomouc City and Olympia), are assumed to experience more significant losses in their footfall.

Thirdly, the primitive typology of retail facilities (traditional centrally-located, suburban newlyconstructed, and revitalised brownfield) and the respective modelled results argue in favour of the revitalisation of disused industrial areas within or near the city centre, and their active use as for example in retail facilities, as well as arguments against the occupation of suburban agricultural land. However, it is fair to admit that the assessment of the location of shopping centres has to take into account more factors, such as economy and transport. As shown above, the gravity model can particularly contribute to the assessment of the latter. Shopping centres in the city centre are very intensive in terms of individual transport; however, they are easily accessible by public transport, too. On the other hand, the location of suburban shopping centres is more favourable for individual and logistic transport, while access by public transport is less convenient.

Finally, we can see that the modelling of spatial interactions and the application of gravity models is able to contribute to the resolution of research tasks, particularly when statistical data on the examined issue are lacking, in our case, when we strive to reveal the spatial patterns of shopping centre footfall.

\section{Acknowledgement}

The article has been supported by the project of the Czech Science Foundation: "Urban and suburban quality of life: a geographical perspective" (P404/11/1811). The authors are grateful for this support.

\section{References:}

AKWAWUA, S., POOLER, J. A. (2001): The development of intervening opportunities model with spatial dominance effects. Journal of Geographical Systems, Vol. 3, No. 1, p. 69-86.

ALONSO, W. (1978): A theory of movement. In: Hansen N. M. [ed.]: Human Settlement Systems: International Perspectives on Structure, Change and Public Policy. Ballinger, Cambridge (Mass.), p. 197-211.

BERRY, B. J. L. (1967): Geography of market centres and retail distribution. Prentice Hall, Englewood Cliffs, 146 pp.

BEZÁK, A. (2000): Interregional migration in Slovakia: some tests of spatial interaction models. Geografický časopis, Vol. 52, No. 1, p. 15-32.

BIRKIN, M., CLARKE, G. P., CLARKE, M. (2002): Retail Geography and Intelligent Network Planning. Wiley, Chichester, 284 pp.

BLUM, B. S., GOLDFARB, A. (2006): Does the internet defy the law of gravity? Journal of International Economics Vol. 70 , No. 2, p. 384-405.

CHEN, Y. (2009): Urban gravity model based on cross-correlation function and Fourier analyses of spatio-temporal process. Chaos, Solitons and Fractals, Vol. 41, No. 2, p. 603-614.

CHOJNICKI, Z. [ed.] (1977): Metody ilościowe i modele w geografii. PAN, Warszawa, 232 pp.

CLIFF, A. D., MARTIN, R. L., ORD, J. K. (1974): Evaluating the friction of distance parameter in gravity models. Regional Studies, Vol. 8, No. 3-4, p. 281-286.

CONVERSE, P. D. (1949): New laws of retail gravitation. Journal of Marketing, Vol. 14, No. 3, p. 379-384.

DE VRIES, J. J., NIJKAMP, P., RIETVELD, P. (2009): Exponential or power distance-decay for commuting? An alternative specification. Environment and planning A, Vol. 41, No. 2, p. 461-480.

DREZNER, T., DREZNER, M. (2007): The gravity p-median model. European Journal of Operational Research, Vol. 179, No. 3, p. 1239-1251.

FISCHER, M. M. (1998): Computational neural networks - a new paradigm for spatial analysis. Environment and Planning A, Vol. 30, No. 10, p. 1873-1892.

FISCHER, M. M., REISMANN, M. (2002): A methodology for neural spatial interaction modelling. Geographical Analysis, Vol. 34, No. 3, p. 207-228.

FISCHER, M. M. (2009): Principles of neural spatial interaction modelling. In: Sonis, M. [ed.]: Reassessment of Theories of Regional Science. Springer, Heidelberg, p. 199-214.

FOTHERINGHAM, A. S. (1981): Spatial structure and distance-decay parameters. Annals of the Association of American Geographers, Vol. 71, No. 3, p. 425-436.

FOTHERINGHAM, A. S. (1985): Spatial competition and agglomeration in urban modelling. Environment and Planning A, Vol. 17, No. 2, p. 213-230. 
FOTHERINGHAM, A. S. (1986): Modelling hierarchical destination choice. Environment and Planning A, Vol. 18, No. 3, p. 401-418.

FOTHERIGHAM, A. S. (2012): Customer store choice and retail competition. In: Pellegrini, L., Reddy, S. K. [eds.]: Retail and marketing channels: economic and marketing perspectives on producer-distributor relationships. Routledge, Oxon, p. 234-257.

FOTHERINGHAM, A. S., BRUNSDON, C., CHARLTON, M. (2000): Quantitative geography: perspectives on spatial data analysis. Sage, London, $270 \mathrm{pp}$.

FOTHERINGHAM, A. S., O`KELLY, M.E. (1989): Spatial interaction models: formulations and applications. Kluwer, London, $244 \mathrm{pp}$.

HAGGETT, P. (1965): Locational Analysis in Human Geography. Arnold, London, 339 pp.

HALÁS, M. (2005): Dopravný potenciál regiónov Slovenska. Geografie, Vol. 110, No. 4, p. 257-270.

HALÁS, M., KLAPKA, P. (2010): Regionalizace Česka z hlediska modelování prostorových interakcí. Geografie, Vol. 115, No. 2, p. 144-160.

HAYNES, K. E., FOTHERINGHAM, A. S. (1984): Gravity and spatial interaction models. Sage, London, 88 pp.

HLAVIČKA, V. (1993): Teoretická východiska a souvislosti konstrukce gravitačních modelů. Geografie, Vol. 98, No. 1, p. 34-43.

HUBÁČKOVÁ, V., KREJČÍ, T. (2007): Regionální vliv Slovácka pohledem Reillyho modelu. In X. mezinárodní kolokvium o regionálních vědách. 1. vyd. Brno, Ekonomicko-správní fakulta MU, p. 220-227.

HUFF, D. L. (1964): Defining and estimating a trading area. Journal of Marketing Vol. 28, No. 3, p. 34-38.

ISARD, W. (1960): Methods of regional analysis: and introduction to regional science. MIT, Cambridge (Mass.), 784 pp.

JOHNSTON, R. J. (1973): On frictions of distance and regression coefficients. Area, Vol. 5, No. 3, p. 187-191.

JOHNSTON, R. J. (2008): Quantitative Human Geography: Are We Turning Full Circle? Geographical Analysis, Vol. 40, No. 3, p. 332-335.

KUNC, J., FRANTÁL, B., SZCZYRBA, Z., TONEV, P., TOUŠEK, V. (2011): Shopping centres and shopping behaviour: selected relations and socio-geographical implications (The Vaňkovka Gallery Brno, Czech Republic example). Acta Universitatis Palackianae Olomucensis - Geographica, Vol. 42, No. 1, p. 5-17.

LEE, M.-L., PACE, R. K. (2005): Spatial Distribution of Retail Sales. The Journal of Real Estate Finance and Economics, Vol. 31, No. 1, p. 53-69.

LI, Y., LIU, L. (2012): Assessing the impact of retail location on store performance: a comparison of Wal-Mart and Kmart stores in Cincinnati. Applied Geography, Vol. 32, No. 2, p. 591-600.

OPENSHAW, S. (1998): Neural network, genetic, and fuzzy logic models of spatial interaction. Environment and Planning A, Vol. 30, No. 10, p. 1857-1872.

Oxford Dictionaries, 2013 [on line]. Accessible at: http://oxforddictionaries.com/definition/english/footfall.

PAULOV, J. (1991): The zone-size-dependent entropy formula and spatial interaction modelling: a note on some implications. Environment and Planning A, Vol. 23, No. 4, p. 557-570.

PLANE, D. A. (1982): An information theoretic approach to the estimation of migration flows. Journal of Regional Science, Vol. 22, No. 4, p. 441-456.

POOLER, J. (1994): An Extended Family of Spatial Interaction Models. Progress in Human Geography, Vol. 18, No. 1, p. 7-39.

RASOULI, S, TIMMERMANS, H. (2013): Assessment of model uncertainty in destinations and travel forecasts of models of complex spatial shopping behaviour. Journal of Retailing and Consumer Services, Vol. 20, No. 2, p. 139-146.

RAVENSTEIN, E. G. (1885): The laws of migration. Journal of Royal Statistical Society, Vol. 48, p. 167-235.

ŘEHÁK, S. (2004): Geografický potenciál pohraničí. In: Jeřábek, M., Dokoupil, J., Havlíček, T. [eds.]: České pohraničí bariéra nebo prostor zprostředkování? Academia, Praha, p. 67-74.

ŘEHÁK, S., HALÁS, M., KLAPKA, P. (2009): Několik poznámek k možnostem aplikace Reillyho modelu. Geographia Moravica, Vol. 1, p. 47-58.

REILLY, W. J. (1931): The law of retail gravitation. Knickerbocker Press, New York, 75 pp.

SCHENK, T. A., LÖFFLER, G., RAUH, J. (2007): Agent-based simulation of consumer behaviour in grocery shopping on a regional level. Journal of Business Research, Vol. 60, No. 8, p. 894-903.

SCOTT, D. M., HE, S. Y. (2012): Modelling constrained destination choice for shopping: a GIS-based, time-geographic approach. Journal of Transport Geography, Vol. 23, p. 60-71.

SENIOR, M. L. (1979): From gravity modelling to entropy maximising: a pedagogic guide. Progress in Human Geography, Vol. 3, No. 2, p. 174-210. 
SHEPPARD, E. S. (1978): Theoretical underpinning of the gravity hypothesis. Geographical Analysis Vol. 10, No, 4, p. $386-402$.

SNICKARS, F., WEIBULL, J. W. (1977): A minimum information principle. Regional Science and Urban Economics, Vol. 7, No. $1-2$, p. 137-168.

STEWART, J. Q. (1948): Demographic gravitation: evidence and applications. Sociometry, Vol. 11, No. 1/2, p. 31-58.

SUÁREZ-VEGA, R., SANTOS-PEŃATE, D. R., DORTA-GONZÁLEZ, P. (2007): The follower location problem with attraction thresholds. Papers in Regional Science, Vol. 86, No. 1, p. 123-137.

SZCZYRBA, Z. (2010): Development of retail geographical structure in the Czech Republic: a contribution to the study of urban environment changes. Acta Universitatis Palackianae Olomucensis - Geographica, Vol. 41, No. 2, p. 5-20.

TAYLOR, P. J. (1971): Distance transformation and distance decay function. Geographical Analysis Vol. 3, No. 3, p. $221-238$.

TAYLOR, P. J. (1983): Distance Decay in Spatial Interactions. CATMOG 2. Geo Books, Norwich, p. 35.

TOBLER, W. (1983): An alternative formulation for spatial-interaction modelling. Environment and Planning A, Vol. 15, No. 5, p. 693-703.

WILSON, A. (2010): Entropy in Urban and Regional Modelling: Retrospect and Prospect. Geographical Analysis, Vol. 42, No. 4, p. 364-394.

WILSON, A. G. (1967): Statistical theory of spatial distribution models. Transportation Research, Vol. 1, p. 253-269.

WILSON, A. G. (1974): Urban and regional models in geography and planning. Wiley, London, 418 pp.

ZIPF, G. K. (1947): The hypothesis of the "minimum equation" as a unifying social principle: with attempted synthesis. American Sociological Review, Vol. 12, No. 6, p. 627-650.

\section{Authors'addresses:}

Mgr. Pavel KLAPKA, Ph.D.

Department of Environmental Geography, Institute of Geonics AS CR, v. v. i.

Drobného 28, 60200 Brno, Czech Republic

e-mail:klapka@geonika.cz

Martin ERLEBACH, e-mail: martin.erlebach@seznam.cz

Ondřej KRÁL, e-mail: ondraspitfire@seznam.cz

Michal LEHNERT, e-mail: michal.lehnert@gmail.com

Tomáš MIČKA, e-mail: tomas.micka@seznam.cz

Department of Geography, Faculty of Science, Palacky University Olomouc

17. listopadu 12, 77146 Olomouc, Czech Republic

Initial submission 1 January 2013, final acceptance 13 August 2013

Please cite this article as:

KLAPKA, P., ERLEBACH, M., KRÁL, O., LEHNERT, M., MIČKA, T. (2013): The footfall of shopping centres in Olomouc (Czech Republic): An application of the gravity model. Moravian Geographical Reports, Vol. 21, No. 3, p. 12-26. DOI: 10.2478/mgr-2013-0013. 